\title{
Heterosis for Yield and its Components in Okra (Abelmoschus esculentus L. Moench)
}

\author{
Prakash Kerure $^{1 *}$, M. Pitchaimuthu ${ }^{2}$, V. Srinivasa ${ }^{3}$ and R. Venugopalan ${ }^{4}$ \\ ${ }^{1}$ ICAR-Krishi Vigyan Kendra, Chitradurga 577 598, Karnataka, India \\ ${ }^{2}$ ICAR-Indian Institute of Horticultural Research, Bengaluru-560 089, Karnataka, India \\ ${ }^{3}$ University of Agricultural and Horticultural Sciences, $\mathrm{COH}$, Mudigere, Karnataka, India \\ ${ }^{4}$ ICAR-Indian Institute of Horticultural Research, Bengaluru-560 089, Karnataka, India
}

*Corresponding author

\section{A B S T R A C T}

The study of heterosis would help in selection of heterotic crosses for commercial exploitation of $F_{1}$ hybrids in okra (Abelmoschus esculentus (L.) Moench). $45 \mathrm{~F}_{1} \mathrm{~s}$ were

\section{Keywords}

Abelmoschus esculentus, $\mathrm{F}_{1}$ hybrids, Heterotic pattern, Hybrid vigour, Parental lines

\section{Article Info}

Accepted: 04 December 2018 Available Online: 10 January 2019 developed by crossing 10 elite lines of okra in half diallel fashion during summer 2016. All $45 \mathrm{~F}_{1} \mathrm{~s}$ along with their 10 parents and one standard control (Nunhems hybrid Shakti) were evaluated in a randomized complete block design with three replicates during late kharif (July to October) 2016 at ICAR- Krishi Vigyan Kendra, Babbur Farm, Hiriyur, Chitradurga, Karnataka, India, for heterosis of yield and its components of okra. Significance of mean squares due to genotypes revealed the presence of considerable genetic variability among the material studied for almost all yield and yield attributes. The overall maximum positive significant heterosis for total yield per plant was observed in cross IIHR-875 x IIHR-478 (112.89\%) over relative heterosis, $(83.78 \%)$ over heterobeltiosis and $(168.55 \%)$ over standard heterosis. Negatively heterotic crosses like IIHR-562 x IIHR-444 for days to $50 \%$ flowering (-8.70\%) and IIHR-567 x IIHR-107 for fruiting nodes $(-9.03 \%)$ respectively, are important to exploit heterosis for earliness in okra. Out of $45 \mathrm{~F}_{1} \mathrm{~s}, 44 \mathrm{~F}_{1} \mathrm{~s}$ crosses exhibit significant standard heterosis in any given direction for total yield per plant except cross IIHR-604 x IIHR-107 (-0.13\%). The $\mathrm{F}_{1}$ hybrid IIHR-875 x IIHR-478 with high yield potential has the potential for commercial cultivation after further evaluation for late kharif season of Karnataka.

\section{Introduction}

Okra is originated in tropical Africa. It is an introduced vegetable crop in India. Although, it is a multipurpose and multifarious crop, it is extensively grown for its tender pods, which are used as a very popular, tasty and gelatinous vegetable. Okra is the most important vegetable crop in India. Among the vegetables grown in India, okra occupies fifth position, next to tomato in area. Yield plateau seems to have been reached in openpollinated varieties of okra. However, it could be improved through hybridization. Marked heterosis of 38 to 71 percent has been reported in okra for yield and its components 
(Laxmiprasanna, 1996, Singh et al., 1975). Heterosis breeding has been the most successful approach in increasing the productivity in cross-pollinated vegetable crops. Okra is one often-cross pollinated vegetable crop where the presence of heterosis was demonstrated for the first time by Vijayaraghavan and Warrier (1946). Since then, heterosis for yield and its components were extensively studied. Selection of parents on the basis of phenotypic performance alone is not a sound procedure. It is therefore essential that parents should be chosen on the basis of their combining ability. The half diallel mating design has been used in the present study to assess the genetic potentialities of the parents in hybrid combination through systematic studies in relation to general and specific combining abilities which are due to additive and nonadditive gene effects respectively (Griffing, 1956; Kempthrone, 1957). Several research workers have reported occurrence of heterosis in considerable quantities for fruit yield and its various components (Venkataramani, 1952; Joshi et al., 1958; Partap and Dhankar, 1980; Elangovan et al., 1981; Partap et al., 1981; Mehta et al., 2007; Weerasekara et al., 2007; Jindal et al., 2009). The ease in emasculation and very high percentage of fruit setting indicates the possibilities of exploitation of hybrid vigour in okra. The presence of sufficient hybrid vigour is an important prerequisite for successful production of hybrid varieties. Therefore, the heterotic studies can provide the basis for the exploitation of valuable hybrid combinations in the future breeding programmes and their commercial utilization. Variation in most of the agronomical and horticultural traits is available in the germplasm of cultivated okra (Dhall et al., 2003; Singh et al., 2006; Dakahe et al., 2007; Mohapatra et al., 2007; Reddy, 2010). The initial selection of parents to be involved in any effective hybridization programme depends upon the nature and magnitude of relative heterosis (heterosis over mid parent), heterobeltiosis (heterosis over better parent), and economic heterosis (heterosis over check) present in genetic stocks. Heterosis breeding based on the identification of the parents and their cross combinations is capable of producing the highest level of transgressive segregates (Falconer, 1960). The choice of the best parental matings is crucial for the development of superior hybrids and because combinations of hybrids grow exponentially with the potential number of parents to be used, this is one of the most expensive and time-consuming steps in hybrid development programmes (Agrawal, 1998). The present investigation aims primarily to study the direction and extent of relative heterosis, heterobeltiosis and economic heterosis for yield and its associated traits in $10 \times 10$ half diallel crosses for utilization of existing genetic diversity to develop heterotic $\mathrm{F}_{1}$ hybrids in okra.

\section{Materials and Methods}

Ten elite and nearly homozygous lines of okra namely IIHR -875 , IIHR -478, IIHR- 604, IIHR- 567, IIHR- 182, IIHR- 595, IIHR- 562, IIHR- 347, IIHR- 444, IIHR-107 selected from the germplasm collected by ICARIndian Institute of Horticulture Research Institute, Bengaluru, Karnataka and were crossed in $n(n-1) / 2$ possible combinations during summer 2016 to generate the breeding material. The resulting 45 one way crosses along with their 10 counterpart parental lines and one standard control (Nunhems Hybrid Shakti) were evaluated in a randomized complete block design with three replicates. The experiment was conducted at the Experimental Farm, ICAR- Krishi Vigyan Kendra, Babbur Farm, Hiriyur, Chitradurga, Karnataka. The experiment was conducted during late kharif (July-October) 2016. Nutrition, irrigation, weed control and other 
cultural practices were followed as per the standard package of practices of UHS, Bagalkot. Biometric data were recorded for 12 quantitative characters. Observations on the characters like plant height $(\mathrm{cm})$, number of branches per plant, internodal length $(\mathrm{cm})$, stem girth $(\mathrm{mm})$, first fruit producing node, fruit length $(\mathrm{cm})$, fruit diameter $(\mathrm{mm})$, number of ridges per fruit and average fruit weight $(\mathrm{g})$ were recorded on five randomly selected competitive plants, while the observations on the characters like days to $50 \%$ flowering, total number of fruits per plant and total yield per plant $(\mathrm{g})$ were recorded on whole plot basis in each entry in each replicate. Relative heterosis, heterobeltiosis and standard heterosis were determined as percent increase $(+)$ or decrease (-) of $\mathrm{F}_{1}$ over mid parent (MP), better parent (BP) and standard control (SC) using the formulae $\left(\mathrm{F}_{1}-\mathrm{MP} / \mathrm{MP} \times 100\right),\left(\mathrm{F}_{1}-\mathrm{BP} / \mathrm{BP} \times\right.$ $100)$ and $\left(\mathrm{F}_{1}-\mathrm{SC} / \mathrm{SC} \times 100\right)$, respectively (Singh, 1973). The statistical significance of heterosis, heterobeltiosis and standard heterosis was assessed by t-test (Wynne et al., 1970).

\section{Results and Discussion}

\section{Mean performance}

From the mean performance of the genotypes, it is evident that, in general, the mean values of crosses were desirably higher than those of the parents (Table 1) for internodal length number of branches per plant, first fruit producing node, days to $50 \%$ flowering fruit length, fruit diameter, average fruit weight, total number of fruits per plant and total yield per plant. On other hand, the mean values of crosses were desirably lower than those of the parents for plant height and stem girth. In general, the range of mean values of parents as a whole was highest for total yield per plant (357.53 to $536.50 \mathrm{~g}$ ) followed by plant height $(103.93$ to $166.30 \mathrm{~cm})$, number of fruits per plant (24.00 to 30.66). Similarly, the range of mean values of crosses as a group was highest for total yield per plant (336.33 to 904.40) followed by plant height (96.27 to $164.43 \mathrm{~cm})$, number of fruits per plant $(22.00$ to 45.67$)$.

The range of mean performance of 10 parental lines and their 45 cross combinations are presented in Table 2. Plant height among the parents and crosses varied from 103.93 to 166.30 and 96.27 to $164.43 \mathrm{~cm}$, respectively. Internodal length varied from 9.20 to 12.39 and 9.23-13.33 cm among the parents and crosses, respectively. Number of branches per plant among the parents and crosses varied from 2.20 to 4.21 and 2.20 to 4.35 , respectively. Stem girth varied from 18.55 to 24.33 and 17.92 to $26.89 \mathrm{~mm}$ among the parents and crosses, respectively. First fruit producing node among the parents and crosses varied from 4.53 to 6.99 and 5.10 to 8.04 , respectively. Days to $50 \%$ flowering varied from 44.00 to 45.66 and 42.00 to 46.33 among the parents and crosses, respectively. Fruit length among the parents and crosses varied from 11.78 to15.05 and 11.07 to 16.81 $\mathrm{cm}$, respectively. Fruit diameter varied from 17.54 to 21.59 and 16.31 to $21.33 \mathrm{~mm}$ among the parents and crosses, respectively. Average fruit weight among the parents and crosses varied from 13.10 to 18.83 and 13.06 to 21.66 g, respectively. No. of ridges per fruit varied from 5.03 to 5.86 and 5.00 to 6.10 among the parents and crosses, respectively. No. of fruits per plant among the parents and crosses varied from 24.0 to 30.66 and 22.00 to 45.67 , respectively. Yield per plant varied from 357.53 to 536.50 and 336.33 to $904.40 \mathrm{~g}$ among the parents and crosses, respectively.

\section{Heterosis}

The range of heterosis and the number of crosses displaying significantly positive and negative heterosis over the mid parent, better 
parent and standard control (Nunhems hybrid Shakti) are presented in Table 2. There was huge amount of variation in heterotic effects as they varied differently for different characters. For plant height, heterosis over mid parent, better parent and standard control ranged from-20.92 to $14.39,-33.30$ to 13.93 and -23.82 to 30.12 respectively. For this trait, 16 cross over mid parent, nine cross over better parent and 36 cross over standard control manifested significantly positive heterosis. Heterosis over mid parent, better parent and standard control ranged from 19.94 to $29.81,-22.03$ to 20.01 and -19.79 to 15.91 respectively for internodal length. For internodal length 15 cross over mid parent, 21 cross over better parent and 11 cross over standard control manifested significantly negative heterosis.

For number of branches per plant, heterosis over mid parent, better parent and standard control ranged from -30.61 to $48.93,-40.11$ to 40.54 and -35.64 to 26.97 respectively. For this trait, 22 cross over mid parent, eight cross over better parent and four cross over standard control manifested significantly positive heterosis. For stem girth, heterosis over mid parent, better parent and standard control ranged from -18.17 to $27.90,-20.70$ to 24.64 and -14.57 to 28.23 respectively. For this trait, 21 cross over mid parent, seven cross over better parent and 18 cross over standard control manifested significantly positive heterosis.

For first fruit producing node, heterosis over mid parent, better parent and standard control ranged from -19.57 to $55.31,-25.44$ to 54.32 and -9.03 to 43.32 respectively. For this trait, 10 cross over mid parent, 15 cross over better parent and six cross over standard control manifested significant heterosis in desirable direction (negative). For days to $50 \%$ flowering, heterosis over mid parent, better parent and standard control ranged from -7.69 to $4.58,-8.03$ to 3.79 and -8.70 to 0.72 respectively. For this trait, seven cross over mid parent, nine cross over better parent and nine cross over standard control manifested significantly negative heterosis.

For fruit length, heterosis over mid parent, better parent and standard control ranged from -19.74 to $32.83,-25.40$ to 24.30 and 25.24 to 13.53 respectively (Table 2 ). For this trait, 17 cross over mid parent, 10 cross over better parent and five cross over standard control manifested significantly positive heterosis. For fruit diameter, heterosis over mid parent, better parent and standard control ranged from -16.76 to $16.81,-23.14$ to 16.01 and -16.77 to 11.90 respectively. For this trait, 14 cross over mid parent, seven cross over better parent and four cross over standard control manifested positively significant heterosis. For average fruit weight, heterosis over mid parent, better parent and standard control ranged from -23.78 to $43.79,-30.05$ to 31.76 and -15.39 to 42.25 respectively. For this trait, 24 cross over mid parent, 16 cross over better parent and 26 cross over standard control manifested significantly positive heterosis. For number of ridges per fruit, heterosis over mid parent, better parent and standard control ranged from -7.55 to 17.31 , 13.07 to 15.09 and -3.85 to 17.31 respectively. For this trait, three cross over mid parent, two cross over better parent and eight cross over standard control manifested significantly positive heterosis.

For number of fruits per plant, heterosis over mid parent, better parent and standard control ranged from -16.98 to $61.18,-24.14$ to 48.91 and -4.35 to 98.55 respectively. For this trait 28 cross over mid parent, 19 cross over better parent and 42 cross over standard control manifested significantly positive heterosis. For total yield per plant, heterosis over mid parent, better parent and standard control ranged from -19.93 to $112.89,-32.66$ to 83.78 
and -0.13 to 168.55 respectively (Table 2). For this trait, 28 cross over mid parent, 20 cross over better parent and 44 cross over standard control manifested positively significant heterosis. From the results of the heterosis studies, it is evident that none of the $45 \mathrm{~F}_{1}$ hybrids of okra showed consistency in direction and degree of heterosis over three bases for all the characters studied. Some of them manifested positive heterosis while others exhibited negative heterosis (data not shown), mainly due to varying extent of genetic diversity between parents of different cross combinations for the component characters. Significant heterosis was observed for all the growth, earliness and yield attributes. It is inferred that the magnitude of economic heterosis was higher for most of the growth and earliness characters under study. In the present study, the estimates of relative heterosis, heterobeltiosis, and standard heterosis were found to be highly variable in direction and magnitude among crosses for all the characters under study. Weerasekara et al., (2007) and Jindal et al., (2009) also reported such a variation in heterosis for different characters. The manifestation of negative heterosis observed in some of the crosses for different traits may be due to the combination of the unfavorable genes of the parents.

Of the 12 characters under study, plant height, number of branches per plant and internodal length largely determine the fruit bearing surface and thus considered as growth attributes. Okra bears pods at almost all nodes on main stem and primary branches. Higher the plant height with more number of branches on the main stem, higher is the number of fruits per plant because of accommodation of more number of nodes for a given internodal length. Shorter distance between nodes accommodates more number of nodes on main stem, which will ultimately lead to higher fruit number and higher fruit production. Hence, positive heterosis is desirable for plant height and number of branches, while negative heterosis is desirable for internodal length to accommodate more number of nodes and to get higher fruit yield in okra. Appreciable amount of the crosses displayed positive standard heterosis for plant height (up to $30.12 \%$ ), no. of branches per plant (up to 26.97\%), internodal length (up to -19.79\%). Ahmed et al., (1999), Dhankar and Dhankar (2001) and Rewale et al., (2003), Singh et al., (2004), Weerasekara et al., (2007) and Jindal et al., (2009) also reported the similar projections for number of branches in okra. For internodal length, similar projections were also made by Rewale et al., (2003), Singh et al., (2004), and Jindal et al., (2009).

Days to $50 \%$ flowering and first fruit producing node are the indicators of earliness in okra. Early flowering not only gives early pickings and better returns but also widens fruiting period of the plant. Fruiting at lower nodes is helpful in increasing the number of fruits per plant as well as getting early yields. Negative heterosis is highly desirable for all these three attributes of earliness. In the present study, cross IIHR-562 x IIHR-444 exhibiting high negative heterosis over standard control for days to $50 \%$ flowering ($8.70 \%$ ) out of 45 hybrids, 7, 9 and 9 hybrids showed significant heterosis in desirable direction (negative) over mid parent, over better parent and over standard parent respectively. The cross IIHR-567 x IIHR-107 displaying high negative heterosis over standard control for first fruit producing node $(-9.03 \%)$ among the 45 hybrids developed, 10 hybrids over mid parent, 25 hybrids over better parent and 6 hybrids over standard parent showed significantly negative heterosis therefore, it is important to exploit heterosis for earliness in okra. Weerasekara et al., (2007) and Jaiprakashnarayan et al., (2008) also noticed heterosis in desirable direction 
for days to $50 \%$ flowering in okra. The negative estimates of heterobeltiosis and economic heterosis for earliness revealed the presence of genes for the development of earliness in okra. Mandal and Das (1991), Tippeswamy et al., (2005) and Jindal et al., (2009) also noticed desirable heterosis for first fruit producing node in okra.

Total number of fruits per plant and fruit length, width, and weight are considered to be associated directly with total yield per plant, for which positive heterosis is desirable. The trait fruit length exhibit high magnitude significant heterosis in both the direction over mid parent, better parent and standard parent. Maximum positive and significant heterosis over mid parent $(32.83 \%)$, over better parent $(24.30 \%)$ and over standard parent $(13.53 \%)$ was observed in crosses IIHR-478 x IIHR567. Among 45 hybrids developed, 18 hybrids over mid parent, 10 hybrids over better parent and 5 hybrids over standard parent exhibited positive and significant heterosis. The trait fruit diameter exhibit high magnitude significant heterosis in both the direction over mid parent, better parent and standard parent. The cross IIHR-478 x IIHR444 exhibited maximum positively significant heterosis over mid parent $(16.81 \%)$, over better parent (16.01\%) and over standard parent (11.90\%). Out of 45 hybrids, 12, 7 and 4 hybrids showed positive and significant heterosis over mid parent, over better parent and over standard parent respectively. The trait average fruit weight exhibit high magnitude significant heterosis in both the direction over mid parent, better parent and standard parent. Positively significant heterosis is preferred for this trait. The cross IIHR-604 x IIHR-182, showed maximum positive significant heterosis over mid parent $(43.79 \%)$ and over better parent $(31.76 \%)$. Whereas, the cross IIHR-478 x IIHR-567 showed maximum significant heterosis over standard parent (42.25\%). Among 45 hybrids,
25 hybrids over mid parent, 13 hybrids over better parent and 26 hybrids over standard parent exhibited significant positive heterosis. Similar results were also reported by Ahmed et al., (1999), Weerasekara et al., (2007) and Jaiprakashnarayan et al., (2008) in okra.

The magnitude of heterosis for number of fruits per plant was significant in both the direction over mid parent, better parent and where only positive direction was seen in standard parent. Maximum positive significant heterosis was observed in cross IIHR-875 x IIHR-478 (61.18\%) over mid parent, (48.91\%) over better parent and $(98.55 \%)$ over standard parent. Majority of crosses exhibits positive and significant heterosis. Out of 45 hybrids, 29 hybrids over mid parent, 19 hybrids over better parent and 42 hybrids over standard parent exhibited positive and significant heterosis. The magnitude of heterosis for total yield per plant was significant in both the direction over mid parent, better parent and where maximum positive direction was seen in standard parent. Maximum positive significant heterosis was observed in cross IIHR-875 $x$ IIHR-478 $(112.89 \%)$ over mid parent, $(83.78 \%)$ over better parent and (168.55\%) over standard parent. Majority of crosses exhibits positive and significant heterosis. Out of the 45 hybrids, 29 hybrids over mid parent, 20 hybrids over better parent and 44 hybrids over standard parent exhibited positive and significant heterosis. Similar results were also reported by Singh et al., (2012), Solankey and Singh, (2010), Sheela et al., (1998), Kumbhani et al., (1993) and Shukla and Gautam, (1990). Indicating that, the predominance of non additive type of genes action and this cross can be commercially exploited to get benefits of non additive type of gene action. Higher magnitude of heterosis observed for fruit yield in the present investigation is attributed to wide genetic variability existing in the germplasm. High magnitude of standard heterosis for fruit yield 
was also reported in earlier studies (Wankhade et al., 1997; Dhankar and Dhankar, 2001; Shukla and Gautam, 1990; Sheela et al., 1998 and Singh et al., 1975). The heterosis observed for total yield per plant was attributed to the heterosis exhibited for growth, earliness and yield parameters. As there is significant genotypic association between yield and yield parameters like fruit length, average fruit weight and number of fruits per plant. Heterosis observed for these component characters have greatly contributed for higher magnitude of heterosis observed for total yield. However, for exploitation of heterosis the information on gca should be supplemented with sca and hybrid performance.

Griffing (1956) has suggested the possibility of working with yield components which are likely to be more simply inherited than is by itself. Grafius (1959) suggested that there is no separate gene system for yield per se and that the yield is an end product of the multiplication interaction between the yield components. The contribution of components of yield is through component compensation mechanism (Adams, 1967). Since then component breeding rather than direct selection on yield has commonly been practiced. It is obvious that high heterosis for yield was built up by the yield components. Hybrid vigour of even small magnitude for individual components may result in significant hybrid vigour for yield per se. This was confirmed by the present investigation where none showed hybrid vigor for yield alone. The high heterosis for fruit yield observed in these crosses could probably be due to combined heterosis of their component characters, as these hybrids were not only heterotic in respect of fruit yield but were also found superior for one or the other yield components. Thus, the observed high heterosis for total yield seems to be due to increase in the total number of fruits per plant rather than increase in the size and weight of fruits, which is a desirable requirement in okra improvement. The results obtained in the present investigation were encouraging and tremendous increase in yield was obtained in most of the hybrids. Based on the overall performance of the hybrids and parental lines, some of the lines could be used as parents of hybrids of okra with high to moderate yield potential.

Significantly positive heterosis has been observed mainly in terms of total yield in crosses over their mid and better parents. The crosses IIHR-875 x IIHR-478, IIHR-604 x IIHR-347 and IIHR-875 x IIHR-604 were the top three heterotic crosses, manifesting an average heterosis of $112.89 \%, 77.96 \%$ and $67.73 \%$ respectively, while the crosses IIHR$875 \times$ IIHR-478, IIHR-875 x IIHR-604 and IIHR-478 $x$ IIHR-567 were the top three heterotic crosses, displaying a heterobeltiosis of $83.78 \% \quad 65.83 \%$ and $63.61 \%$, respectively, where as the crosses IIHR-875 x IIHR-478, IIHR-604 x IIHR-347 and IIHR$478 \times$ IIHR-562 were the top three heterotic crosses, manifesting an standard heterosis of $168.55 \%, 133.05 \%$ and $95,62 \%$ respectively for total yield per plant (Table 3). These results are in agreement with the findings of Weerasekara et al., (2007) and Jaiprakashnarayan et al., (2008). However, crosses IIHR-875 x IIHR-478, IIHR-478 x IIHR-567 and IIHR-604 $\mathrm{x}$ IIHR-347 displaying $168.55 \%, 159.53 \%$ and $133.05 \%$ respectively significant standard heterosis in any given direction are as promising as that of standard control (Table 5). It is apparent that the high heterosis for total fruit yield may probably be due to dominance nature of genes. The significantly positive heterobeltiosis for total yield per plant could be apparently due to preponderance of fixable gene effects, which is also reported by Elangovan et al., (1981) and Singh et al., (1996). 
Higher magnitude of heterosis observed for fruit yield in the present investigation is attributed to wide genetic variability existing in the germplasm. High magnitude of standard heterosis for fruit yield was also reported in earlier studies (Wankhade et al., 1997; Dhankar and Dhankar, 2001; Shukla and Gautam, 1990; Sheela et al., 1998 and Singh et al., 1975). The heterosis observed for total yield per plant was attributed to the heterosis exhibited for growth, earliness and yield parameters. As there is significant genotypic association between yield and yield parameters like fruit length, average fruit weight and number of fruits per plant. Heterosis observed for these component characters have greatly contributed for higher magnitude of heterosis observed for total yield. However, for exploitation of heterosis the information on gca should be supplemented with sca and hybrid performance.

Table.1 Range and average performance of parents, crosses and control in okra

\begin{tabular}{|l|c|c|c|c|c|}
\hline \multirow{2}{*}{} & \multicolumn{2}{|c|}{ Parents } & \multicolumn{2}{c|}{ Crosses } & Control \\
& Range & Mean & Range & Mean & mean \\
\cline { 2 - 6 } & $103.93-166.30$ & 144.13 & $96.27-164.43$ & 140.50 & 129.67 \\
\hline Plant height (cm) & $9.20-12.39$ & 11.18 & $9.23-13.33$ & 11.21 & 12.33 \\
\hline No. of branches per plant & $2.20-4.21$ & 2.88 & $2.20-4.35$ & 3.06 & 3.00 \\
\hline Stem girth (mm) & $18.55-24.33$ & 21.41 & $17.92-26.89$ & 21.27 & 20.94 \\
\hline First fruit producing node & $4.53-6.99$ & 5.78 & $5.10-8.04$ & 6.05 & 5.67 \\
\hline Days to 50\% flowering & $44.00-45.66$ & 44.80 & $42.00-46.33$ & 44.87 & 45.00 \\
\hline Fruit length (cm) & $11.78-15.05$ & 13.25 & $11.07-16.81$ & 13.71 & 14.84 \\
\hline Fruit diameter (mm) & $17.54-21.59$ & 18.55 & $16.31-21.33$ & 18.57 & 19.67 \\
\hline Average fruit weight (g) & $13.10-18.83$ & 15.79 & $13.06-21.66$ & 16.88 & 19.40 \\
\hline No. of ridges per fruit & $5.03-5.86$ & 5.22 & $5.00-6.10$ & 5.22 & 5.00 \\
\hline No. of fruits per plant & $24.00-30.66$ & 28.27 & $22.00-45.67$ & 31.50 & 34.00 \\
\hline Yield per plant (g) & $357.53-536.50$ & 452.99 & $336.33-904.40$ & 543.74 & 564.40 \\
\hline
\end{tabular}

Table.2 Ranges of heterosis over three bases and number of crosses with significantly positive and negative heterosis for twelve traits in okra

\begin{tabular}{|c|c|c|c|}
\hline \multicolumn{2}{|c|}{ Heterosis } & Range & \multicolumn{2}{c|}{ No. of heterotics } \\
\cline { 3 - 4 } & \multicolumn{2}{|c|}{ Positive } & Negative \\
\hline Plant height $(\mathbf{c m})$ & $-20.92 * *$ to $14.39 * *$ & 16 & 26 \\
\hline RH & $-33.30 * *$ to $13.93 * *$ & 9 & 31 \\
\hline HB & $-23.82 * *$ to $30.12 * *$ & 36 & 7 \\
\hline SH & & 22 & 15 \\
\hline RH & $-19.94 * *$ to $29.81 * *$ & 3 & 21 \\
\hline HB & $-22.03 * *$ to $20.01 * *$ & 5 & 11 \\
\hline SH & $-19.79 * *$ to $15.91 * *$ & \\
\hline No. of branches per plant & & & 6 \\
\hline RH & $-30.61 * *$ to $48.93 * *$ & 22 & 15 \\
\hline HB & $-40.11 * *$ to $40.54 * *$ & 8 & \\
\hline
\end{tabular}




\begin{tabular}{|c|c|c|c|}
\hline SH & $-35.64 * *$ to $26.97 * *$ & 4 & 23 \\
\hline \multicolumn{4}{|l|}{ Stem girth $(\mathbf{m m})$} \\
\hline $\mathbf{R H}$ & $-18.17 * *$ to $27.90^{* *}$ & 21 & 25 \\
\hline HB & $-20.70 * *$ to $24.64 * *$ & 7 & 23 \\
\hline SH & $-14.57 * *$ to $28.23 * *$ & 18 & 12 \\
\hline \multicolumn{4}{|c|}{ First fruit producing node } \\
\hline RH & $-19.57 * *$ to $55.31 * *$ & 18 & 10 \\
\hline HB & $-25.44 * *$ to $54.32 * *$ & 7 & 15 \\
\hline SH & $-9.03 * *$ to $43.32 * *$ & 26 & 6 \\
\hline \multicolumn{4}{|c|}{ Days to $50 \%$ flowering } \\
\hline RH & $-7.69^{* *}$ to $4.58^{* *}$ & 6 & 7 \\
\hline HB & $-8.03^{* *}$ to $3.79^{* *}$ & 2 & 9 \\
\hline SH & $-8.70^{* *}$ to $0.72^{* *}$ & - & 9 \\
\hline \multicolumn{4}{|l|}{ Fruit length $(\mathrm{cm})$} \\
\hline RH & $-19.74 * *$ to $32.83 * *$ & 17 & 9 \\
\hline HB & $-25.40 * *$ to $24.30 * *$ & 10 & 16 \\
\hline SH & $-25.24 * *$ to $13.53 * *$ & 5 & 27 \\
\hline \multicolumn{4}{|c|}{ Fruit diameter (mm) } \\
\hline RH & $-16.76^{* *}$ to $16.81^{* *}$ & 14 & 12 \\
\hline HB & $-23.14 * *$ to $16.01 * *$ & 7 & 14 \\
\hline SH & $-16.77 * *$ to $11.90^{* *}$ & 4 & 25 \\
\hline \multicolumn{4}{|c|}{ Average fruit weight (g) } \\
\hline RH & $-23.78 * *$ to $43.79 * *$ & 24 & 14 \\
\hline HB & $-30.05^{* *}$ to $31.76^{* *}$ & 16 & 18 \\
\hline SH & $-15.39 * *$ to $42.25 * *$ & 26 & 6 \\
\hline \multicolumn{4}{|c|}{ No. of ridges per fruit } \\
\hline RH & $-7.55^{* *}$ to $17.31 * *$ & 3 & 6 \\
\hline HB & $-13.07 * *$ to $15.09 * *$ & 2 & 11 \\
\hline SH & $-3.85^{* *}$ to $17.31 * *$ & 8 & 1 \\
\hline \multicolumn{4}{|c|}{ No. of fruits per plant } \\
\hline RH & $-16.98 * *$ to $61.18 * *$ & 28 & 11 \\
\hline HB & $-24.14 * *$ to $48.91 * *$ & 19 & 13 \\
\hline SH & $-4.35 * *$ to $98.55^{* *}$ & 42 & - \\
\hline \multicolumn{4}{|c|}{ Yield per plant (g) } \\
\hline RH & $-19.93^{* *}$ to $112.89^{* *}$ & 28 & 8 \\
\hline HB & $-32.66 * *$ to $83.78 * *$ & 20 & 15 \\
\hline SH & $-0.13^{* *}$ to $168.55^{* *}$ & 44 & - \\
\hline
\end{tabular}

$*, * *$ Significant at $\mathrm{P} \leq 0.05$ and $\mathrm{P} \leq 0.01$ levels, respectively,

RH: Relative Heterosis; HB: Heterobeltiosis; SH: Standard Heterosis 
Table.3 Top three crosses with significant heterosis in desirable direction for 12 traits in okra

\begin{tabular}{|c|c|c|c|}
\hline & & Heterosis (\%) & \\
\hline & RH & HB & SH \\
\hline \multirow{3}{*}{$\begin{array}{l}\text { Plant } \\
\text { height } \\
\text { (cm) }\end{array}$} & $\begin{array}{c}\text { (IIHR-875 x IIHR-604) } \\
14.39 * *\end{array}$ & $\begin{array}{c}\text { (IIHR-875 x IIHR-604) } \\
13.93 * *\end{array}$ & $\begin{array}{c}\text { (IIHR-875 x IIHR-604) } \\
30.12 * *\end{array}$ \\
\hline & $\begin{array}{c}\text { (IIHR-875 x IIHR-444) } \\
10.81 * *\end{array}$ & $\begin{array}{c}\text { (IIHR-478 x IIHR-107) } \\
6.72 * *\end{array}$ & $\begin{array}{l}\text { (IIHR-875 x IIHR-567) } \\
28.81 * *\end{array}$ \\
\hline & $\begin{array}{c}\text { (IIHR-875 x IIHR-182) } \\
7.95 * *\end{array}$ & $\begin{array}{c}\text { (IIHR-478 x IIHR-604) } \\
6.31 * *\end{array}$ & $\begin{array}{c}\text { (IIHR-567 x IIHR-595) } \\
24.82 * *\end{array}$ \\
\hline \multirow{3}{*}{$\begin{array}{l}\text { Inter } \\
\text { nodal } \\
\text { length } \\
\text { (cm) }\end{array}$} & $\begin{array}{c}\text { (IIHR-595 x IIHR-562) - } \\
19.94 * *\end{array}$ & $\begin{array}{c}\text { (IIHR-562 x IIHR-444) - } \\
22.03 * *\end{array}$ & $\begin{array}{c}\text { (IIHR-562 x IIHR-444) - } \\
19.79 * *\end{array}$ \\
\hline & $\begin{array}{c}\text { (IIHR-562 x IIHR-444) - } \\
14.92 * *\end{array}$ & $\begin{array}{c}\text { (IIHR-595 x IIHR-562) - } \\
21.74 * *\end{array}$ & $\begin{array}{c}\text { (IIHR-595 x IIHR-562) - } \\
15.71 * *\end{array}$ \\
\hline & $\begin{array}{c}\text { (IIHR-604 x IIHR-182) - } \\
12.36 * *\end{array}$ & $\begin{array}{l}\text { (IIHR-444 x IIHR-107) - } \\
20.08 * *\end{array}$ & $\begin{array}{c}\text { (IIHR-444 x IIHR-107) - } \\
15.01 * *\end{array}$ \\
\hline \multirow{3}{*}{$\begin{array}{l}\text { No. of } \\
\text { branche } \\
\text { s per } \\
\text { plant }\end{array}$} & $\begin{array}{l}\text { (IIHR-562 x IIHR- } \\
\text { 107) } 48.93 * *\end{array}$ & $\begin{array}{c}\text { (IIHR-562 x IIHR-107) } \\
40.54 * *\end{array}$ & $\begin{array}{c}\text { (IIHR-182 x IIHR-347) } \\
26.97 * *\end{array}$ \\
\hline & $\begin{array}{c}\text { (IIHR-875 x IIHR-562) } \\
46.03 * *\end{array}$ & $\begin{array}{c}\text { (IIHR-595 x IIHR-562) } \\
35.57 * *\end{array}$ & $\begin{array}{c}\text { (IIHR-875 x IIHR-604) } \\
21.32 * *\end{array}$ \\
\hline & $\begin{array}{c}\text { (IIHR-595 x IIHR-562) } \\
42.35 * *\end{array}$ & $\begin{array}{c}\text { (IIHR-875 x IIHR- 604) } \\
33.98 * *\end{array}$ & $\begin{array}{c}\text { (IIHR-875 x IIHR-478) } \\
20.06 * *\end{array}$ \\
\hline \multirow{3}{*}{$\begin{array}{l}\text { Stem } \\
\text { girth } \\
(\mathbf{m m})\end{array}$} & $\begin{array}{c}\text { (IIHR-595 x IIHR-347) } \\
27.90 * *\end{array}$ & $\begin{array}{c}\text { (IIHR-595 x IIHR-347) } \\
24.64 * *\end{array}$ & $\begin{array}{c}\text { (IIHR-595 x IIHR-347) } \\
28.23 * *\end{array}$ \\
\hline & $\begin{array}{c}\text { (IIHR-595 x IIHR-562) } \\
12.58 * *\end{array}$ & $\begin{array}{c}\text { (IIHR-182 x IIHR-107) } \\
9.79 * *\end{array}$ & $\begin{array}{c}\text { (IIHR-478 x IIHR-562) } \\
15.27 * *\end{array}$ \\
\hline & $\begin{array}{c}\text { (IIHR-182 x IIHR-107) } \\
11.01 * *\end{array}$ & $\begin{array}{l}\text { (IIHR-595 x IIHR-562) } \\
8.61 * *\end{array}$ & $\begin{array}{c}\text { (IIHR-478 x IIHR-604) } \\
14.78 * *\end{array}$ \\
\hline \multirow{3}{*}{$\begin{array}{l}\text { First } \\
\text { fruit } \\
\text { produci } \\
\text { ng node }\end{array}$} & $\begin{array}{c}\text { (IIHR-567 x IIHR-107) - } \\
19.57 * *\end{array}$ & $\begin{array}{c}\text { (IIHR-562 x IIHR-444) - } \\
25.44 * *\end{array}$ & $\begin{array}{c}\text { (IIHR-567 x IIHR-107) - } \\
9.03 * *\end{array}$ \\
\hline & $\begin{array}{c}\text { (IIHR-182 x IIHR-595) - } \\
17.63 * *\end{array}$ & $\begin{array}{c}\text { (IIHR-567 x IIHR-107) - } \\
24.99 * *\end{array}$ & $\begin{array}{c}\text { (IIHR-182 x IIHR-595) - } \\
8.38^{* *}\end{array}$ \\
\hline & $\begin{array}{c}\text { (IIHR-562 x IIHR-347) - } \\
13.50 * *\end{array}$ & $\begin{array}{c}\text { (IIHR-182 x IIHR-595) - } \\
19.01 * *\end{array}$ & $\begin{array}{c}\text { (IIHR-444 x IIHR-107) - } \\
8.32 * *\end{array}$ \\
\hline \multirow{3}{*}{$\begin{array}{l}\text { Days to } \\
\mathbf{5 0 \%} \\
\text { flowerin } \\
\text { g }\end{array}$} & $\begin{array}{c}\text { (IIHR-562 x IIHR-444) - } \\
7.69 * *\end{array}$ & $\begin{array}{c}\text { (IIHR-562 x IIHR-444) - } \\
8.03 * *\end{array}$ & $\begin{array}{c}\text { (IIHR-567 x IIHR-107) - } \\
8.70 * *\end{array}$ \\
\hline & $\begin{array}{c}\text { (IIHR-567 x IIHR-444) - } \\
6.96 * *\end{array}$ & $\begin{array}{c}\text { (IIHR-567 x IIHR-444) - } \\
7.30 * *\end{array}$ & $\begin{array}{c}\text { (IIHR-567 x IIHR-444) - } \\
7.97 * *\end{array}$ \\
\hline & $\begin{array}{l}\text { (IIHR-567 x IIHR-107) - } \\
6.32 * *\end{array}$ & $\begin{array}{c}\text { (IIHR-595 x IIHR-347) - } \\
5.97 * *\end{array}$ & $\begin{array}{c}\text { (IIHR-875 x IIHR-444) - } \\
5.15 * *\end{array}$ \\
\hline \multirow{3}{*}{$\begin{array}{l}\text { Fruit } \\
\text { length } \\
\text { (cm) }\end{array}$} & $\begin{array}{c}\text { (IIHR-478 x IIHR-567) } \\
32.83 * *\end{array}$ & $\begin{array}{c}\text { (IIHR-478 x IIHR-567) } \\
24.30 * *\end{array}$ & $\begin{array}{c}\text { (IIHR-478 x IIHR-567) } \\
13.53 * *\end{array}$ \\
\hline & $\begin{array}{c}\text { (IIHR-875 x IIHR-107) } \\
21.36 * *\end{array}$ & $\begin{array}{c}\text { (IIHR-875 x IIHR-107) } \\
20.58 * *\end{array}$ & $\underset{* *}{(\text { IIHR-478 x IIHR-347) } 9.21}$ \\
\hline & $\begin{array}{c}\text { (IIHR-182 x IIHR-595) } \\
20.78 * *\end{array}$ & $\begin{array}{c}\text { (IIHR-478 x IIHR-107) } \\
16.84 * *\end{array}$ & $\underset{* *}{(I I H R-182 \times \text { IIHR-595) } 8.69}$ \\
\hline Fruit & (IIHR-478 x IIHR-444) & (IIHR-478 x IIHR-444) & (IIHR-478 x IIHR-444) \\
\hline
\end{tabular}




\begin{tabular}{|c|c|c|c|}
\hline \multirow{3}{*}{$\begin{array}{l}\text { diamete } \\
\mathbf{r}(\mathbf{m m})\end{array}$} & $16.81 * *$ & $16.01 * *$ & $11.90 * *$ \\
\hline & $\begin{array}{c}\text { (IIHR-478 x IIHR-567) } \\
15.49 * *\end{array}$ & $\begin{array}{c}(\mathrm{IIHR}-478 \times \text { IIHR-567) } \\
15.00 * *\end{array}$ & $\begin{array}{c}\text { (IIHR-478 x IIHR-567) } \\
10.94 * *\end{array}$ \\
\hline & $\begin{array}{c}\text { (IIHR-875 x IIHR-567) } \\
13.85 * *\end{array}$ & $\begin{array}{c}\text { (IIHR-875 x IIHR-567) } \\
10.49 * *\end{array}$ & $\begin{array}{c}(\mathrm{IIHR}-875 \text { x IIHR-595) } 6.19 \\
* *\end{array}$ \\
\hline \multirow{3}{*}{$\begin{array}{l}\text { Average } \\
\text { fruit } \\
\text { weight } \\
\text { (g) }\end{array}$} & $\begin{array}{c}\text { (IIHR-604 x IIHR-182) } \\
43.79 * *\end{array}$ & $\begin{array}{c}\text { (IIHR-604 x IIHR-182) } \\
31.76 * *\end{array}$ & $\begin{array}{c}\text { (IIHR-478 x IIHR-567) } \\
42.25 * *\end{array}$ \\
\hline & $\begin{array}{c}\text { (IIHR-875 x IIHR-604) } \\
32.17 * *\end{array}$ & $\begin{array}{c}\text { (IIHR-875 x IIHR-562) } \\
30.22 * *\end{array}$ & $\begin{array}{c}\text { (IIHR-347 x IIHR-444) } \\
37.39 * *\end{array}$ \\
\hline & $\begin{array}{c}\text { (IIHR-478 x IIHR-567) } \\
28.93 * *\end{array}$ & $\begin{array}{c}\text { (IIHR-875 x IIHR-604) } \\
29.58 * *\end{array}$ & $\begin{array}{l}\text { (IIHR-604 x IIHR-182) } \\
36.14 * *\end{array}$ \\
\hline \multirow{3}{*}{$\begin{array}{l}\text { No. of } \\
\text { ridges } \\
\text { per fruit }\end{array}$} & $\begin{array}{c}\text { (IIHR-478 x IIHR-444) } \\
17.31 * *\end{array}$ & $\begin{array}{c}\text { (IIHR-478 x IIHR-444) } \\
15.09 * *\end{array}$ & $\begin{array}{c}\text { (IIHR-478 x IIHR-444) } \\
17.31 * *\end{array}$ \\
\hline & $\begin{array}{c}\text { (IIHR-875 x IIHR-562) } \\
9.64 * *\end{array}$ & $\begin{array}{c}\text { (IIHR-875 x IIHR-562) } \\
3.41 *\end{array}$ & $\begin{array}{c}\text { (IIHR-875 x IIHR-562) } \\
16.67 * *\end{array}$ \\
\hline & $\begin{array}{c}\text { (IIHR-604 x IIHR-107) } \\
3.87 *\end{array}$ & - &  \\
\hline \multirow{3}{*}{$\begin{array}{l}\text { No. of } \\
\text { fruits } \\
\text { per } \\
\text { plant }\end{array}$} & $\begin{array}{c}\text { (IIHR-875 x IIHR-478) } \\
61.18 * *\end{array}$ & $\begin{array}{c}\text { (IIHR-875 x IIHR-478) } \\
48.91 * *\end{array}$ & $\begin{array}{c}\text { (IIHR-875 x IIHR-478) } \\
98.55 * *\end{array}$ \\
\hline & $\begin{array}{c}\text { (IIHR-875 x IIHR-347) } \\
58.82 * *\end{array}$ & $\begin{array}{c}\text { (IIHR-875 x IIHR-347) } \\
46.74 * *\end{array}$ & $\begin{array}{c}\text { (IIHR-875 x IIHR-347) } \\
95.65 * *\end{array}$ \\
\hline & $\begin{array}{c}(\text { IIHR-478 x IIHR-562) } \\
37.93 * *\end{array}$ & $\begin{array}{c}\text { (IIHR-478 x IIHR-567) } \\
78.26 * *\end{array}$ & $\begin{array}{c}\text { (IIHR-604 x IIHR-347) } \\
85.51 * *\end{array}$ \\
\hline \multirow{3}{*}{$\begin{array}{l}\text { Yield } \\
\text { per } \\
\text { plant } \\
\text { (g) }\end{array}$} & $\begin{array}{c}\text { (IIHR-875 x IIHR-478) } \\
112.89 * *\end{array}$ & $\begin{array}{c}\text { (IIHR-875 x IIHR-478) } \\
83.78 * *\end{array}$ & $\begin{array}{c}\text { (IIHR-875 x IIHR-478) } \\
168.55 * *\end{array}$ \\
\hline & $\begin{array}{c}\text { (IIHR-604 x IIHR-347) } \\
77.96 * *\end{array}$ & $\begin{array}{c}\text { (IIHR-875 x IIHR-604) } \\
65.83 * *\end{array}$ & $\begin{array}{l}\text { (IIHR-604 x IIHR-347) } \\
133.05 * *\end{array}$ \\
\hline & $\begin{array}{c}\text { (IIHR-875 x IIHR-604) } \\
67.73 * *\end{array}$ & $\begin{array}{c}(\mathrm{IIHR}-478 \times \text { IIHR-567) } \\
63.61 * *\end{array}$ & $\begin{array}{c}\text { (IIHR-478 x IIHR-562) } \\
95.62 * *\end{array}$ \\
\hline
\end{tabular}

$*$, **Significant at $\mathrm{P} \leq 0.05$ and $\mathrm{P} \leq 0.01$ levels, respectively.

RH: Relative Heterosis; HB: Heterobeltiosis; SH: Standard Heterosis

Table.4 Top three crosses on the basis of per se performance and heterotic effects for total yield per plant in okra

\begin{tabular}{|c|c|c|c|c|c|}
\hline \multirow{2}{*}{ Hybrid } & \multicolumn{3}{|c|}{ Heterosis (\%) } & $\begin{array}{c}\text { Mean } \\
\text { performance } \\
\text { (g/plant) }\end{array}$ & $\begin{array}{l}\text { Significance of heterosis } \\
\text { in desired direction }\end{array}$ \\
\cline { 2 - 5 } & $\begin{array}{c}\text { Standard } \\
\text { Control }\end{array}$ & $\begin{array}{c}\text { Better } \\
\text { parent }\end{array}$ & $\begin{array}{c}\text { Mid } \\
\text { parent }\end{array}$ & \\
\hline $\begin{array}{c}\text { IIHR-875 x IIHR- } \\
\mathbf{4 7 8}\end{array}$ & $168.55 * *$ & $83.78 * *$ & $112.89 * *$ & 904.40 & $\begin{array}{l}\text { Number of branches per } \\
\text { plant, first fruit producing } \\
\text { node, average fruit } \\
\text { weight, number of fruits } \\
\text { per plant and total yield } \\
\text { per plant }\end{array}$ \\
\hline IIHR-478 x IIHR- & $159.53 * *$ & $63.61 * *$ & $70.32 * *$ & 874.00 & \\
\hline
\end{tabular}




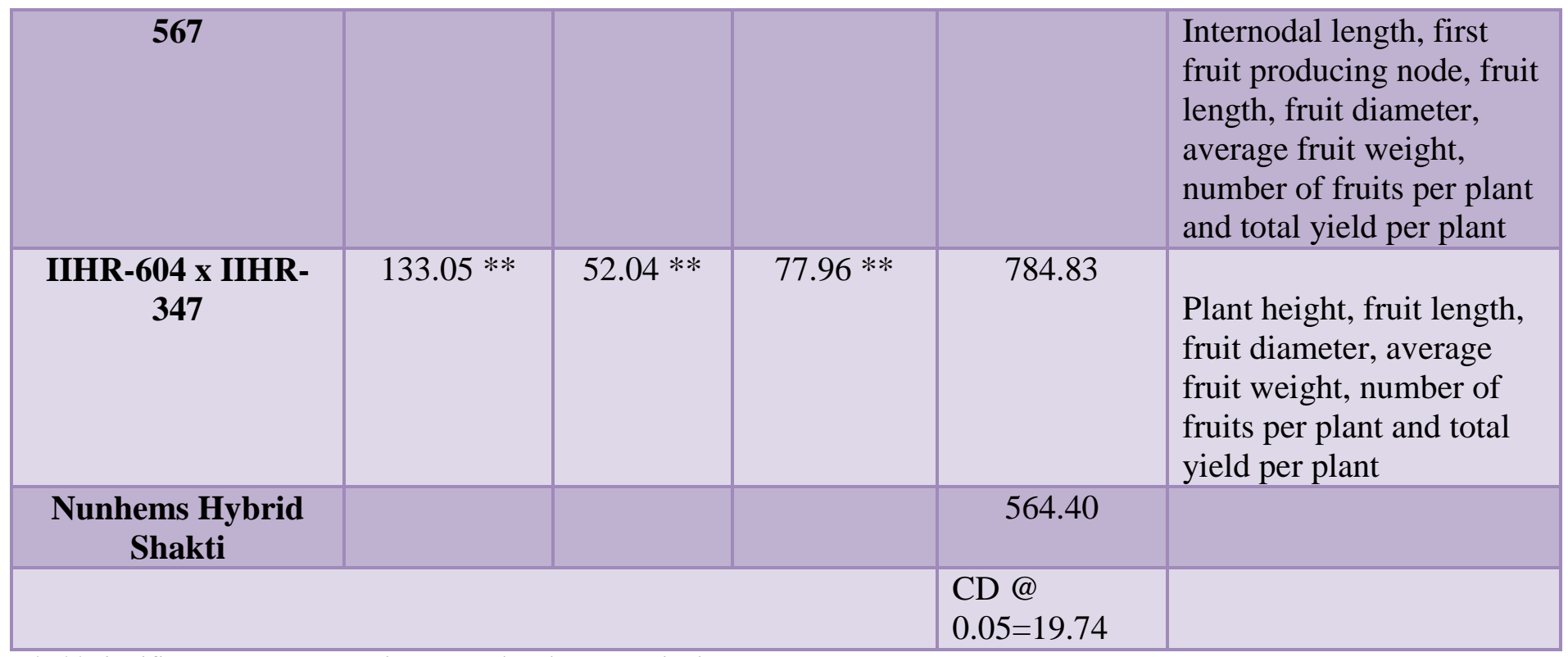

*, **Significant at $\mathrm{P} \leq 0.05$ and $\mathrm{P} \leq 0.01$ levels, respectively.

$\mathrm{CD}$ : Critical difference (including whole data).

RH: Relative Heterosis; HB: Heterobeltiosis; SH: Standard Heterosis

In the present study, it is apparent that high heterosis for yield may probably be due to dominance nature of genes. For yield attributes, some crosses were nonheterotic which may be ascribed to cancellation of positive and negative effects exhibited by the parents involved in a cross combination and can also happen when the dominance is not unidirectional as also pointed out by Gardner and Eberhart (1966) and Mather and Jinks (1982). Heterosis is thought to result from the combined action and interaction of allelic and non allelic factors and is usually closely and positively correlated with heterozygosity (Falconer and Mackay, 1986). According to Swaminathan et al., (1972) heterobeltiosis of more than $20 \%$ over better parent could offset the cost of hybrid seed. Thus, the crosses showing more than $20 \%$ of heterobeltiosis viz. may be exploited for hybrid okra production. Although the range of average heterosis and heterobeltiosis manifested by the crosses for different characters was comparatively wide, but it might not be of much significance unless it shows sufficient gain over the standard control. In the present study, the moderate extent of relative heterosis and heterobeltiosis as observed for yield and yield components could be attributed to its often-cross pollinated nature.

Total yield per plant in crosses IIHR-875 x IIHR-478, IIHR-478 x IIHR-567 and IIHR$604 \times$ IIHR-347 displaying 168.55\%, $159.53 \%$ and $133.05 \%$ respectively significant standard heterosis in any given direction are as promising as that of standard control (Table 4) and mean performance was higher significant differences than standard control (Nunhems Hybrid Shakti) which can be exploited for commercial cultivation after further testing during late kharif of Karnataka.

In conclusions on an average, okra displays heterosis for yield and its component traits studied. However, for each trait important differences exist among hybrids for the individual values of heterosis. Yield components should be considered to increase the yield through selections. The overall maximum positive significant heterosis for total yield per plant was observed in cross IIHR-875 x IIHR-478 (112.89\%) over relative heterosis, $(83.78 \%)$ over heterobeltiosis and 
(168.55\%) over standard heterosis. Negatively heterotic crosses like IIHR-562 x IIHR-444 for days to $50 \%$ flowering $(-8.70 \%)$ and IIHR-567 x IIHR-107 for fruiting nodes $(-9.03 \%)$ respectively, are important to exploit heterosis for earliness in okra. The $\mathrm{F}_{1}$ hybrid IIHR-875 $x$ IIHR-478 with high yield potential has the potential for commercial cultivation after further evaluation for late kharif season of Karnataka.

\section{Acknowledgements}

The authors are highly grateful to the ICARIndian Institute of Horticulture Research Institute, Bengaluru, Karnataka, for providing the germplasm of okra from which the parents for the present study were selected.

\section{References}

Adams, M.W. 1967. Plant architecture and yield breeding. Iowa State Journal of Research 56: 225-254.

Agrawal, R.L. 1998. Fundamentals of plant breeding and hybrid seed production. Science Publishers, Enfield, New Hampshire, USA.

Ahmed, N., M.A. Hakim, and M.Y. Gandroo. 1999. Exploitation of hybrid vigour in okra (Abelmoschus esculentus (L.) Moench). Indian Journal of Horticulture 56: 247-251.

Anonymous, 2015, Indian Horticulture Data Base, 2015, Gurgaon, India, p. 17.

Bose, B. K. and Ranjan, 1988. ICMR Special Report, Series No. 94.

Dakahe, K., H.E. Patil, and S.D. Patil. 2007. Genetic variability and correlation studies in okra (Abelmoschus esculentus (L.) Moench). The Asian Journal of Horticulture 2: 201-203.

Dhall, R.K., S.K. Arora, T.S. Dhillon, and R. Bansal. 2003. Evaluation of advance generations in okra (Abelmoschus esculentus (L.) Moench) for yield and yield contributing characters. Environment and Ecology 21: 95-98.

Dhankar, B. S. and Dhankar, S. K. 2001, Heterosis and combining ability studies for some economic characters in okra. Haryana Journal of Horticulture Science 30: 230-233.

Dhankar, B.S., and S.K. Dhankar. 2001. Heterosis and combining ability studies for some economic characters in okra. Haryana Journal of Horticultural Science 30: 230-233.

Elangovan, M., C.R. Muthurkrishnan, and I. Irulappan. 1981. Combining ability in bhendi (Abelmoschus esculentus (L.) Moench). South Indian Horticulture 29(1-4): 15-22.

Falconer, D.C. 1960. Introduction to quantitative genetics. p. 254. Oliver and Boyd, Edinburgh, Scotland.

Falconer, D.S., and T.F.C. Mackay. 1986. Introduction to quantitative genetics. Longman Group Ltd., Harlow, England.

Gardner, C.O., and S.S. Eberhart. 1966. Analysis and interpretation of the variety cross diallel and related population. Biometrics, 22: 439-452.

Grafius, J. 1959. Heterosis in barley. Agronomy Journal 51: 551-554.

Griffing, B. 1956. Concept of general and specific combining ability in relation to diallel crossing system. Australian Journal of Biological Sciences 9: 463493.

Jaiprakashnarayan, R.P., S.J. Prashanth, R. Mulge, and M.B. Madalageri. 2008. Study on heterosis and combining ability for earliness and yield parameters in okra (Abelmoschus esculentus (L.) Moench). The Asian Journal of Horticulture 3:136-141.

Jindal, S.K., D. Arora, and T.R. Ghai. 2009. Heterobeltiosis and combining ability for earliness in okra (Abelmoschus esculentus (L.) Moench). Crop 
Improvement 36(2): 59-66.

Joshi, A.B., H.B. Singh, and P.S. Gupta. 1958. Studies in hybrid vigour III Bhendi. Indian Journal of Genetics and Plant Breeding18: 57-68.

Kempthorne, O., 1957. An introduction to genetic statistics. John Wiley and Sons, New York, pp. 408-711.

Kumbhani, R.P., Godhani, P.R. and Fougat, R.S., 1993, Hybrid vigour in eight parent diallel cross in okra (Abelmoschus esculentus (L.) Moench). GAU Research Journal 18(2): 13-18.

Laxmiprasanna, J. R., 1996. Genetic studies in okra (Abelmoschus esculentus (L.) Moench). M.Sc. Thesis, Univ. Agric. Sci., Dharwad.

Mandal, N., and N.D. Das. 1991. Heritability and heterosis study in okra (Abelmoschus esculentus (L.) Moench). Experimental Genetics $7(1): 22-25$.

Mather, K., and J.L. Jinks. 1982. Biometrical genetics. 3rd ed. Chapman and Hall Ltd., London, UK.

Mehta, N., B.S. Asati, and S.R. Mamidwar. 2007. Heterosis and gene action in okra. Bangladesh Journal of Agricultural Research 32: 421-432.

Mohapatra, M.R., P. Acharya, and S. Sengupta. 2007. Variability and association analysis in okra. Indian Agriculturist 51(1/2): 17-26.

Partap, P.S., and B.S. Dhankar. 1980. Heterosis studies in okra (Abelmoschus esculentus (L.) Moench). Haryana Agricultural University Journal of Research 18: 336-340.

Partap, P.S., B.S. Dhankar, and M.L. Pandita. 1981. Heterosis and combining ability in okra (Abelmoschus esculentus (L.) Moench). Haryana Journal of Horticultural Science 10: 122-127.

Reddy, M.T. 2010. Genetic diversity, heterosis, combining ability and stability in okra (Abelmoschus esculentus (L.) Moench). Ph.D. thesis. Acharya N.G. Ranga Agricultural University, Rajendranagar, Hyderabad.

Rewale, V.S., V.W. Bendale, S.G. Bhave, R.R. Madav, and B.B. Jadhav. 2003. Heterosis for yield and yield components in okra. Journal of Maharashtra Agricultural Universities 28:247-249.

Sheela, M. N., Manikantan, N. P. and Gopinathan, N. V., 1998. Heterosis in bhendi. Agric. Res. J. Kerala, 26(1): 23-28.

Shukla, A. K. and Gautam, N. C., 1990. Heterosis and inbreeding depression in okra (Abelmoschus esculentus (L.) Moench). Indian Journal of Horticulture 47: 85-88.

Singh A. K., Singh, M. C. and Sanjay Pandey, 2012. Line $\mathrm{x}$ tester analysis for combining ability in okra [Abelmoschus esculentus (L.) moench]. Agriculture Science Digest 32: 91 - 97.

Singh, B., A.K. Pal, and S. Singh. 2006. Genetic variability and correlation analysis in okra (Abelmoschus esculentus (L.) Moench). Indian Journal Horticulture 63(3):63-66.

Singh, B., S. Singh, A.K. Pal, and M. Rai. 2004. Heterosis for yield and yield components in okra (Abelmoschus esculentus (L.) Moench). Vegetable Science 31:168-171.

Singh, D. 1973. Diallel analysis over environments-I. Indian Journal of Genetics and Plant Breeding 33:127136.

Singh, N., S.K. Arora, T.R. Ghai, and T.S. Dhillon. 1996. Heterobeltiosis studies in okra (Abelmoschus esculentus (L.) Moench). Punjab Vegetable Grower 31:18-24. 
Singh, S. P., Srivastava, J. P. and Singh, H. N., 1975. Heterosis in bhendi (Abelmoschus esculentus (L.) Moench.). South Indian Horticulture 40: 21-27.

Solankey, S. S. and Singh, A. K., 2010. Studies on combining ability in okra [Abelmoschus esculentus (L.) Moench]. The Asian Journal of Horticulture 5(1): 49-53.

Swaminathan, M.S., E.A. Siddique, and S.D. Sharma. 1972. Outlook for hybrid rice in India. p. 609-613. In Rice breeding. International Rice Research Institute (IRRI), Los Baños, Philipinnes.

Tippeswamy, S., M. Pitchaimuthu, O.P. Dutta, J.S.A. Kumar, and M.C. Ashwini. 2005. Heterosis studies in okra (Abelmoschus esculentus (L.) Moench) using male sterile lines. Journal of Asian Horticulture 2(1):915.

Venkataramani, K.S. 1952. Preliminary studies of some intervarietal crosses and hybrid vigour in Hibiscus esculentus (L). Journal of Madras Agricultural University 22:183-200.

Vijayaraghavan, C., and V.A. Warrier. 1946. Evolution of high yielding hybrid bhindi (Hibiscus esculentus L). $163 \mathrm{p}$. Proceeding of the 33rd Indian Science Congress, Bangalore, India.

Wankhade, R.V., Kale, P.B. and Dod, V.N., 1997. Studies on heterobeltiosis in okra. PKV Research Journal 21(1): 16-21.

Weerasekara, D., R.C. Jagadeesha, M.C. Wali, P.M. Salimath, R.M. Hosamani, and I.K. Kalappanawar. 2007. Heterosis for yield and yield components in okra. Vegetable Science 34: 106-107.

Wynne, J.C., D.A. Emery, and P.M. Rice. 1970. Combining ability estimates in Arachis hypogeae L. II. Field performance of $F_{1}$ hybrids. Crop Science 10: 713-715.

\section{How to cite this article:}

Prakash Kerure, M. Pitchaimuthu, V. Srinivasa, and Venugopalan, R. 2019. Heterosis for Yield and its Components in Okra (Abelmoschus esculentus L. Moench). Int.J.Curr.Microbiol.App.Sci. 8(01): 353-367. doi: https://doi.org/10.20546/ijcmas.2019.801.036 